\title{
$\mathrm{Fe}$ 基液体急冷非晶質合金薄帯上への 無電解 $\mathrm{CoP}$ 合金めっき膜の形成
}

\author{
丸山耕一 ${ }^{*}$, 沼田博雄 ${ }^{* *}$, 大野 湶 ${ }^{* *}$, 佐藤 駿 ${ }^{* *}$
}

\section{Formation of CoP Alloy Films Electroless-Deposited on Rapid-Quenched Amorphous Ribbons}

\author{
Kohichi MARUYAMA*, Hiroo NUMATA**, Izumi OHNO** and Takashi SATO**
}

\begin{abstract}
By using rapid-quenched amorphous alloy ribbons and electro- and electroless-deposited films, we plan to develop novel composite magnetic materials. For this purpose, we form magnetic CoP alloy films electrolessdeposited on rapid-quenched $\mathrm{Fe}$-based amorphous ribbons. Optimum conditions for film formation are determined using electrochemical polarization. The present study focuses on catalysis effects, the influence of amorphous ribbon surfaces (wheel and free sides), and the composition of amorphous ribbons on properties. The crystallinity of resultant films is evaluated by XRD and SEM.
\end{abstract}

Key Words : Bilayer Magnetic Material, Electroless Deposition, Polarization Curve, Rapid-Quenched Amorphous Substrate, CoP Alloy Film

\section{1. 緒言}

液体急冷法により作製した $\mathrm{Fe}$ 基非晶質合金薄膜は優 れた軟磁気特性を示す。一方, 無電解めっき法による薄 膜形成は，合金組成や膜厚を容易に制御でき，基板の種 類を選ばない成膜法である。非晶質薄帯基板上に無電解 めっき法により磁性薄膜を形成する 2 層材を検討する。 基板とめっき層をともに磁性層にすることにより, それ らの磁気的な相互作用や，基板の軟磁気特性によるバイ アス磁界効果が期待できる。またこの 2 層材は, 液体急 冷法と湿式プロセスにより形成されることから, 高生産 性が期待でき, 低価格な磁気記録材料などへの応用が拡 大されると考えられる。

液体急冷非晶質薄帯を基板に用いためっき膜の形成は, 我々の調べた限りではこれまでに試みられていない。本 研究の目的は, Fe 基非晶質薄帯基板上に，良好な無電 解めっき膜形成の可能性を電気化学的分極测定 ${ }^{1)}$ から 評価し, 非晶質基板のめっき面の特性と関連づけて, めっ き速度の制御因子を検討することである。無電解 Coめっ きについては古くから磁性膜としての製法, 特性につい

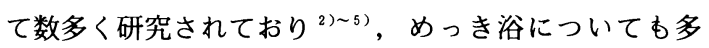
(の浴種が知られている ${ }^{6)}$, 7)。本研究では, 硫酸コバ ルトに, 次亜リン酸ナトリウムを還元剤とし，クエン酸 ナトリウムを錯化剤として用いる無電解 CoPめっき浴 を採用する。このめっき浴の化学組成や $\mathrm{pH}$, 温度など

* 東京工業大学 大学院（テ152 東京都目黒区大岡山2-12-1） Graduate School, Tokyo Inst. of Tech. (12-1, O-okayama 2-chome, Meguro-ku, Tokyo 152)

** 東京工業大学 工学部 (T152 東京都目黒区大岡山 2-12-1) Fac. of Eng., Tokyo Inst. of Tech. (12-1, O-okayama 2-chome, Meguro-ku, Tokyo 152)
のめっき条件は, $\mathrm{Cu}$ 基板を用いて行った場合の最適化 条件を参考に決定する。一般に，単ロール法により作製 した非晶質薄帯のロール面とフリ一面とは, 異なる性質 を持つことが知られている ${ }^{8)}$ 。すなわち、ロール面には ロールのレプリカやエアポケットと呼ばれる凹凸が存在 するのに対し，フリ一面はより平滑なモーフォロジを持 つ点が異なる。無電解めっき浴中で基板に用いた非晶質 薄帯のロール面とフリ一面をそれぞれめっき面とした場 合の, 電流一電位曲線の測定により, 基板面の違いや, その前処理方法, 基板組成依存性を調べ, 無電解めっき 法の最適化を図る。

\section{2. 実験方法}

基板に使用した液体急冷 $\mathrm{Fe}$ 基非晶質合金薄帯は, 単口ー ル法により鋳造されたものである。 $3.5 \mathrm{~cm}$ 幅の FeSiB 組成 (S 265), FeCoSiB 組成 (S 247) の薄帯を $4 \mathrm{~cm}$ 程度の長さに切り, めっきされる面の反対側を耐薬品性, 耐絶縁性, 耐熱性のテープ（日東テープ）で被覆し，基 板として用いた。比較のために，数種類の組成の異なる 非晶質薄帯基板を用い，これらの薄帯の組成を表 1 にま とめて示す。また, 基板の結晶性による違いを調べるた めに多結晶 $\mathrm{Cu}$ 基板を用いた。すべての基板に対して同 一の無電解 CoPめっき浴を用い, この浴の化学組成と めっき温度, 浴の $\mathrm{pH}$ を表 2 に示す。

電気化学的分極測定は，ポテンショスタット（Hokuto Denko Ltd. HA-301) を用い, 関数発生器による電位 走查 $\left(1 \times 10^{-3} \mathrm{~V} / \mathrm{s}\right)$ を行う。電位值と電流值の記録に はデジタル XYレコーダ（Yokogawa LR 4110）を用 いた。また, 対極には Pt 電極を, 参照極には飽和銀一 塩化銀電極（SSE）を用い，恒温槽中に测定電極をセッ 
Table 1 Species and compositions (at. \%) of amorphous ribbons.

\begin{tabular}{c|l}
\hline Substrate No. & \multicolumn{1}{c}{ Compositions } \\
\hline $\mathrm{S} 265$ & $\mathrm{Fe}_{84} \mathrm{Si}_{1} \mathrm{~B}_{15}$ \\
$\mathrm{~S} 247$ & $\mathrm{Fe}_{74} \mathrm{Co}_{10} \mathrm{Si}_{2} \mathrm{~B}_{14}$ \\
$\mathrm{~S} 263$ & $\mathrm{Fe}_{84} \mathrm{~B}_{16}$ \\
$\mathrm{~S} 285$ & $\mathrm{Fe}_{85} \mathrm{~B}_{15}$ \\
$\mathrm{~S} 287$ & $\mathrm{Fe}_{85} \mathrm{Si}_{1} \mathrm{~B}_{14}$ \\
$\mathrm{~S} 803$ & $\mathrm{Fe}_{72.5} \mathrm{Si}_{13.5} \mathrm{~B}_{9} \mathrm{Nb}_{3} \mathrm{Cu}_{2}$ \\
$\mathrm{Z} 667$ & $\mathrm{Fe}_{70} \mathrm{Co}_{12} \mathrm{~B}_{12} \mathrm{C}_{4} \mathrm{Mo}_{2}$ \\
$\mathrm{Z} 802$ & $\mathrm{Fe}_{72} \mathrm{Co}_{10} \mathrm{~B}_{12} \mathrm{C}_{4} \mathrm{Mo}_{2}$ \\
\hline
\end{tabular}

Table 2 Chemical compositions of electroless CoP plating bath and plating compositions.

\begin{tabular}{c|c}
\hline Chemicals & Compositions/M \\
\hline $\mathrm{Na}$-citrate & 0.2 \\
$\mathrm{CoSO}_{4} \cdot 7 \mathrm{H}_{2} \mathrm{O}$ & 0.1 \\
$\mathrm{NaH}_{2} \mathrm{PO}_{2} \cdot \mathrm{H}_{2} \mathrm{O}$ & 0.2 \\
$\mathrm{H}_{3} \mathrm{BO}_{3}$ & 0.5 \\
\hline $\mathrm{pH}$ & 8.2 (with $\mathrm{NaOH}$ ) \\
Bath Temp. & $85^{\circ} \mathrm{C}$ \\
\hline
\end{tabular}

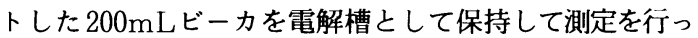
た。めっき浴から，金属イオンを除いた浴（アノード部 分浴）でのアノード酸化曲線と, 還元剤を除いた浴（力 ソード部分浴）での金属イオンのカソード還元曲線と, 金属イオンと還元剤をともに含む浴 (全体浴) 中でアノー ド分極曲線およびカソード分極曲線をそれぞれ測定した。

基板のめっき前処理方法はすべての基板において以下 の方法により行った。アルカリ溶液 $\left(\mathrm{Na}_{2} \mathrm{CO}_{3} 5.25 \mathrm{~g}\right.$ $/ \mathrm{L} ， 50^{\circ} \mathrm{C} ）$ による洗浄処理を施し， $10 \% \mathrm{HCl}$ 溶液で酸 洗した後, 触媒活性処理を施さない場合は充分水洗し, 施す場合には塩化スズ溶液 $\left(40 \mathrm{~g} / \mathrm{L} \mathrm{SnCl}_{2} \cdot 2 \mathrm{H}_{2} \mathrm{O}+\right.$ $20 \mathrm{~mL} / \mathrm{L} \mathrm{HCl}$ ) に浸せき（2 分間）し，次いで塩化パ ラジゥム溶液 $\left(0.3 \mathrm{~g} / \mathrm{L} \mathrm{PdCl}_{2} \cdot 2 \mathrm{H}_{2} \mathrm{O}+5 \mathrm{~mL} / \mathrm{L} \mathrm{HCl}\right)$ に浸せき（1 分間）した後，充分水洗を行った。

実際のめっきは, $100 \mathrm{~mL}$ トルビーカ中に, 基板の 片端をクリップで固定して行った。非晶質基板について は, 触媒活性処理を施したロール面をめっき面として使 用した。無電解めっきした CoP膜の基礎特性として, $\mathrm{X}$ 線回折装置 (JEOL, JDX-35HS)（線源 : $\mathrm{Cu}-\mathrm{K} \alpha$ ) によりめっき膜の結晶性と優先配向性を確認した。また, 表面形態は SEM（JEOL，JSM-89 OS）により観察し た。

\section{3、結果およひ考察}

\section{1 基板の影電}

はじめに, 典型的な酸化還元型の無電解めっきを示す 多結晶 $\mathrm{Cu}$ 基板の場合之, 非晶質基板の場合とを比較す
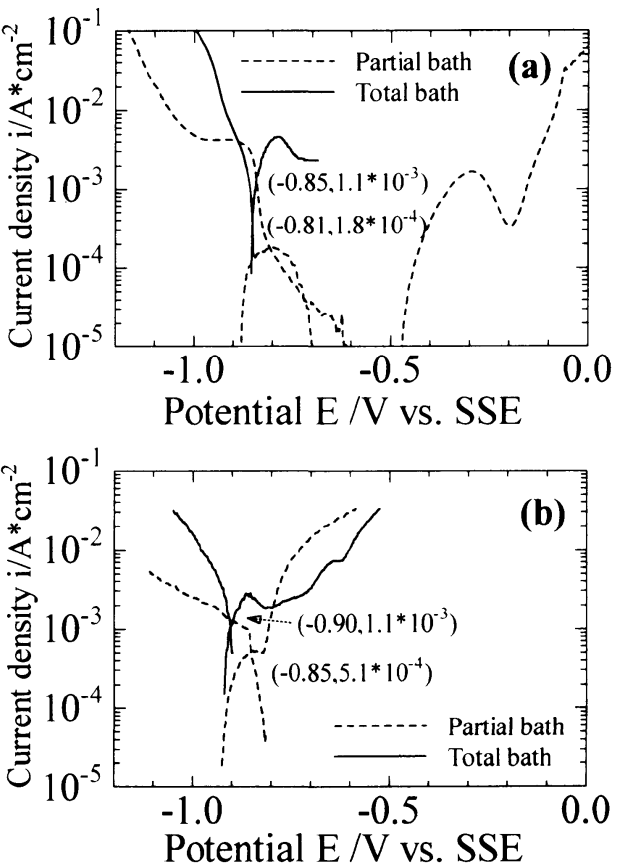

Fig. 1 Polarization properties for the catalyzed (a) polycrystalline $\mathrm{Cu}$ substrate and (b) wheel side surface of FeSiB (S 265) amorphous substrate. The solid and dotted lines describe the polarization curves for the total and the partial bath, respectively.

る。両基板表面を触媒活性処理した場合の全体浴と部分 浴でのアノード分極曲線およびカソード分極曲線を，(a) が $\mathrm{Cu}$ 基板の場合，(b) が $\mathrm{FeSiB}$ (S 265) 非晶質基板の 場合について図 1 に示す。図中の実線と点線とは, それ ぞれ全体浴，部分浴での分極曲線を示す。ただし，両基 板ともに，基板面は $1 \mathrm{~cm}^{2}$ の正方形の夕ーゲット以外 は絶縁テープで覆った。特に，非晶質基板はロール面を 基板表面として使用した。両基板の場合とも，点線で示 す部分浴でのアノード分極曲線とカソード分極曲線との 交点の電位 $E_{\mathrm{P}}$ （めっき電位）とその電位での電流密度 の值 $i_{\mathrm{P}}$ (めっき速度), 全体浴のそれらから外挿するこ とにより予想されるめっき電位 $E_{\mathrm{T}}$ およびめっき速度 $i_{\mathrm{T}}$ の値とは一致が見られない。めっき電位に関しては, 全 体浴の場合が部分浴の場合よりも卑な電位方向にずれて いる。また，めっき電流値に関しても，全体浴において より大きな值を示すことが分かる。このようなずれは, 部分浴でのアノードおよびカソード分極特性が，それぞ れの部分反応が独立であるという仮定の上で測定されて おり，実際のめっき浴（全体浴）中では，還元剤の存在 でカソード反応は促進され，また金属イオンの存在でア ノード反応も加速されるので, 両部分反応は互いに独立 でなく影響し合うことにより生ずる ${ }^{9)}$ 。非晶質薄帯基板 
（以下，非晶質基板と略称する）を用いた場合でも触媒 活性化処理を施せば, 無電解 CoPめっき反応は, 自己 触媒的に進行することが示された。また, 多結晶 $\mathrm{Cu}$ 基 板の場合（図 1 (a)）では，めっき電位は $-0.81 \mathrm{~V} \mathrm{SSE}$ であるのに比して, 非晶質基板の場合（図 1 (b)）では -0.90V SSEとより卑側にずれ，めっき電流值もわず かに大きくなっている。従って, 非晶質基板を用いる場 合には $\mathrm{Cu}$ 基板を用いる場合とほぼ同程度かわずかに大 きいめっき速度で無電解めっきが行われることが分かっ た。

\section{2 触媒化処理の効果}

$\mathrm{Cu}$ 基板の場合には基板自身は触媒活性作用を持たず, $\mathrm{Pd}$ により触媒活性化された場合に無電解 $\mathrm{CoP}$ めっが 可能となる。非晶質基板の自己触媒作用を確認するため に, $\mathrm{FeSiB}$ (S 265) 基板を例に取り, 触媒活性処理を施 した場合と施さない場合とで分極測定を行った結果を図 2 (a)，(b) に示す。(a) は部分浴での分極曲線を，(b) は全体浴でのそれを示している。図中の実線と点線は, それぞれ触媒活性処理を施した場合と施さない場合とに 対応する。ただし, 薄帯基板のフリ一面をテープで被覆 して, ロール面のみの分極特性を測定した。部分浴, 全 体浴ともに，また，アノード分極曲線とカソード分極曲 線ともに，曲線の傾向は非常によく似ている。しかし， 触媒活性処理を施すことによりCo析出のめっき電位が 貴の方向に移行することが，両浴について共通した特性 として挙げられる。ただし, その電位での電流密度の值 が, 触媒活性処理を施すことにより, 部分浴では5.0$5.1 \times 10^{-4} \mathrm{~A} / \mathrm{cm}^{2}$ とほとんよ゙変わらないのに対して，全 体浴では $4.7 \times 10^{-4} \mathrm{~A} / \mathrm{cm}^{2}$ から $1.1 \times 10^{-3} \mathrm{~A} / \mathrm{cm}^{2}$ に大 きくなる点が異なる。これは，全体浴においては還元剤 の存在により Co の析出を示すカソード分極曲線が貴方 向に大きくシフトすることに起因している。この分極特 性の観察から，非晶質基板には， $\mathrm{Cu}$ 基板之は異なり， 還元剤のアノード酸化に対して触媒活性があるが，充分 なめっき速度を得られるほど大きくはなく，Pdによる 触媒活性処理により実用的なめっき速度が得られること が推測され，実際のめっき速度の結果と一致する。ただ し, $\mathrm{FeCoSiB}$ (S 247) 非晶質基板のロール面の場合には, 分極曲線は省略するが, 自己触媒作用が大きく, 活性処 理なしであ充分なめっき速度が得られることが確認され た。このことは, 非晶質基板の組成を選ぶことにより触 媒活性の大きい基板を選ぶことができ, 活性化処理の工 程を除いても実用的なめっき速度が得られることが示唆 される。しかしながら，めっき速度への基板表面の形態 による違いや，酸化層の影響などが推測され，さらなる 確認が必要である。

\section{3 非晶兵基板のロール面とフリー面との相遳}

単ロール法により作製される非晶質薄帯は, 前述した
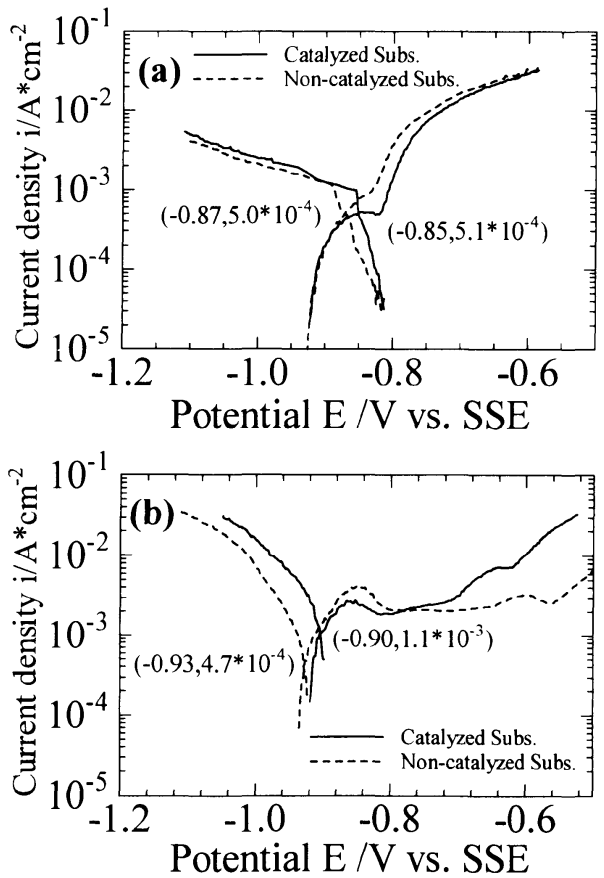

Fig. 2 Polarization curves for the catalyzed and non-catalyzed amorphous substrates. The curves are described by the solid and the dotted lines, respectively. (a) and (b) show polarization properties in the partial and the total bath, respectively, using the wheel side surface of $\mathrm{FeSiB}(\mathrm{S} 265)$ substrates.

ように，フリ一面とロール面とで性質が異なるため，そ れぞれの面をめっき面とした場合の分極特性を比較した あのを図 3 に示す。(a) に部分浴，(b) に全体浴における 分極曲線を示す。図中の実線と点線は，それぞれ触媒活 性処理を施していない FeSiB 組成 (S 265) の薄帯基板 のフリー面，ロール面の場合に対応する。ただし，両面 の非晶質性はX線回折 (XRD) 曲線のハローなパ夕ー ンより確認した。部分浴, 全体浴ともにフリ一面の場合 がロール面の場合に比へ，分極曲線が貴方向に移行して いる。それに従い，めっき電位あ貴の方向にある。この フリー面とロール面との違いは, 図2で示したロール面 を触媒活性処理を施した場合と施さない場合との違いに 類似している。全体浴のカソード分極曲線は，ロール面 よりも約 $200 \mathrm{mV}$ あ大きく貴方向にシフトしている。実 際, この非晶質基板のフリ一面に Pdによる触媒活性処 理を施しても分極曲線に大きな変化がないことを確認し た。これらの分極特性の結果から，この組成の基板に関 する限りでは，フリ一面の方がロール面より大きなめっ き速度が得られるあの之推測される。しかし,これあ先 に述べた $\mathrm{FeCoSiB}$ (S 247) 非晶質基板の例を考えても， 一般的な特性であるとは言い難い。 


\section{4 非晶質基板組成の影留}

以上の分極特性の結果と考察は, 非晶質基板について は，すべて同一の組成（FeSiB(S 265））に関して考え てきた。次に，組成の異なる非晶質基板を用いて，分極 特性を測定し，比較する。それぞれの基板を用いて測定 した電流一電位曲線より得られた部分浴, 全体浴でのめっ き速度 $\left(i_{\mathrm{P}}, i_{\mathrm{T}}\right)$ とめっき電位 $\left(E_{\mathrm{P}}, E_{\mathrm{T}}\right)$ を，表 3 に 示す。これらは，ロール面とフリ一面を等面積浸せきし, 測定した場合の結果を示している。そのいくつかの非晶 質基板を用いて，部分浴での分極曲線を比較した結果を 図 4 に示す。図中に，表 1 に対応する試料 No.を示した。 (a)にアノード分極曲線，(b) にカソード分極曲線を示す。 さらに，これらの非晶質基板を用いた分極特性の結果か ら得られためっき電位 $(E)$ とめっき速度 $(i)$ の関係 を図 5 (a) に示す。まず，部分浴では，図4 (a) から，特 にアノード曲線が，基板の組成に大きく依存しているこ とが分かる。また，基板組成によりめっき電位が大きく 変化し，図 5 (a) からは，それが杽であるほどめっき速 度は指数関数的に增加している。このことから, 部分浴 でのアノード反応は非晶質基板の電極触媒活性に大きく 依存していることが分かる。一方，全体浴での分極曲線 は, アノード曲線とカソード曲線について，表 3 に示し
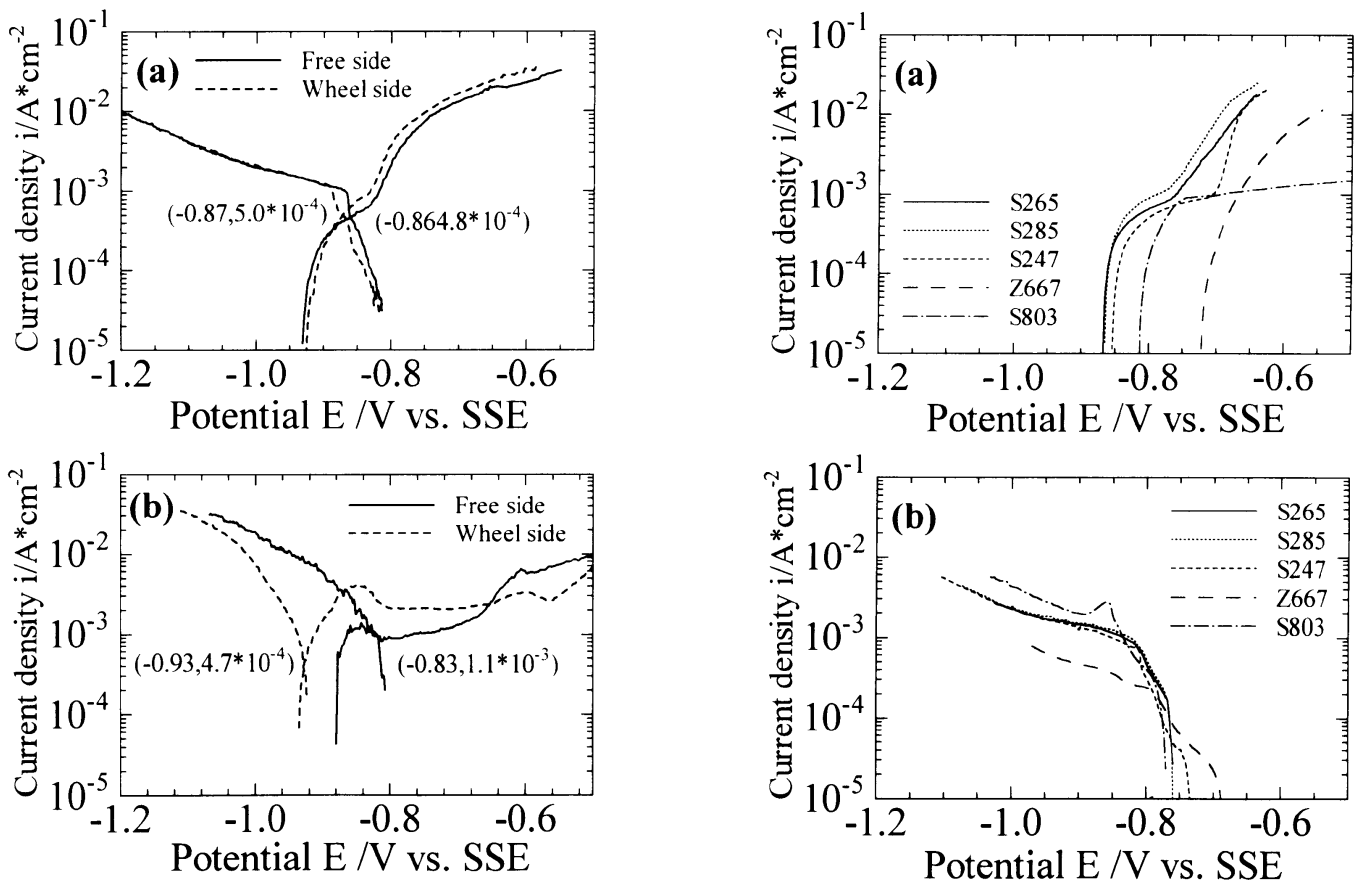

Fig. 3 Polarization curves for the non-catalyzed free side and wheel side surfaces of $\mathrm{FeSiB}(\mathrm{S} 265)$ amorphous substrates, which are described by the solid and the dotted lines, respectively. (a) and (b) show polarization properties in the same way as Fig. 2

Fig. 4 Polarization properties in the partial bath, for several amorphous substrates. (a) and (b) show the anodic and the cathodic poralization curves, respectively.

Table 3 Electrochemical polarization measurements for various amorphous substrates. Plating velocity and plating potential are denoted by $i$ and $E$, respectively. Subscripts, $\mathrm{T}$ and $\mathrm{P}$, mean the total bath and the partial bath, respectively.

\begin{tabular}{c|c|c|c|c}
\hline Substrate No & $i_{\mathrm{p}} / 10^{-4} \mathrm{~A} \times \mathrm{cm}^{-2}$ & $E_{\mathrm{P}} / \mathrm{mV}$ & $i_{\mathrm{r}} / 10^{-4} \mathrm{~A} \times \mathrm{cm}^{-2}$ & $E_{\mathrm{T}} / \mathrm{mV}$ \\
\hline S 265 & 6.3 & -806 & 4.0 & -849 \\
S 247 & 4.6 & -808 & 5.5 & -856 \\
S 263 & 5.5 & -804 & 6.6 & -850 \\
S 285 & 8.0 & -813 & 8.6 & -857 \\
S 287 & 8.7 & -811 & 8.5 & -847 \\
S 803 & 3.1 & -789 & 3.1 & -846 \\
Z 667 & 0.4 & -719 & 4.5 & -852 \\
Z 802 & 1.3 & -731 & 3.2 & -851 \\
\hline
\end{tabular}



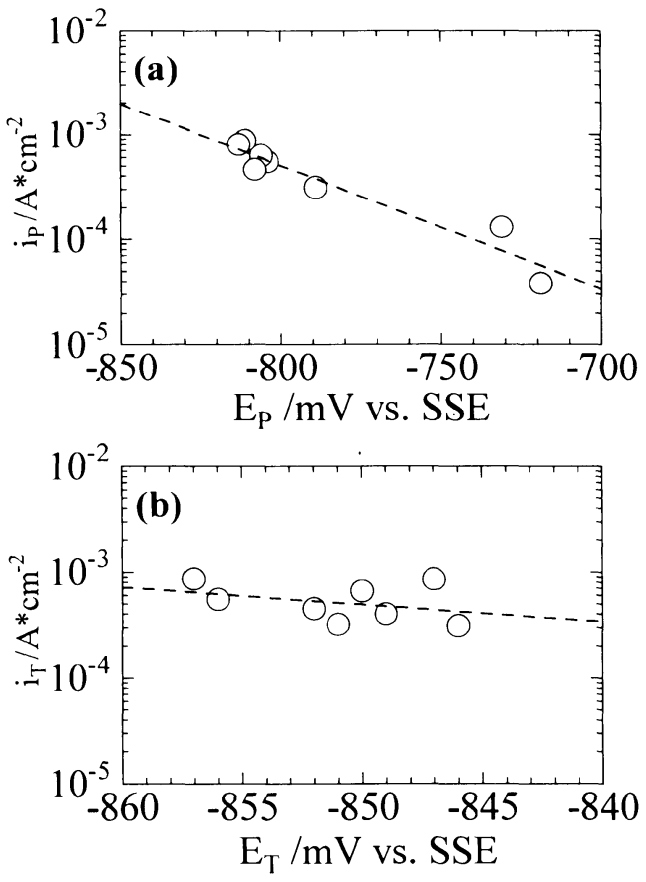

Fig. 5 For several substrates, plating rate (i) vs. plating potential $(E)$. (a) and (b) describe the results in the case of the partial bath and the total bath, respectively.

たようにすべての組成の基板で浸せき電位もほぼ等しく, めっき電位の大きさに広がりがない点で, 部分浴ほどの 大きな基板組成依存性は見られない。しかしながら，ア ノード曲線とカソード曲線はめっき電位からの立ち上が りの勾配が基板組成により異なり，それがめっき速度の 違いとして反映するすのと推測される。その結果を図 5 (b)に示した。部分浴ほど顕著ではないが, めっき速度 がめっき電位に対して指数関数的な関係にあることが分 かる。このようなめっき速度とめっき電位の関係につい て非常に興味深い結果を得たが, 非晶質基板の種類によ り異なる電極触媒能のメカニズムを明らかにし, 観察さ れた全体浴と部分浴との分極挙動の違いの原因を考える 必要がある。

\section{5 電析膜の結晶性}

実際に無電解めっきによって得られた CoP 膜の結 晶配向性をXRD法により調べた結果を図 6 に示す。 多結晶 $\mathrm{Cu}$ 基板を用いた場合 (a) と, 非晶質基板として $\mathrm{FeCoSiB}(\mathrm{S} 247$ ) 基板 (b) と $\mathrm{FeSiB}(\mathrm{S} 265)$ 基板 (c) を用 いた場合とを比較した。基板はすべて同じ条件で触媒活 性処理を施し，同様のめっき条件で 1 時間めっきしたも のを使用した。ただし，非晶質基板についてはロール 面上にめっきを行った。すべての膜において，およそ

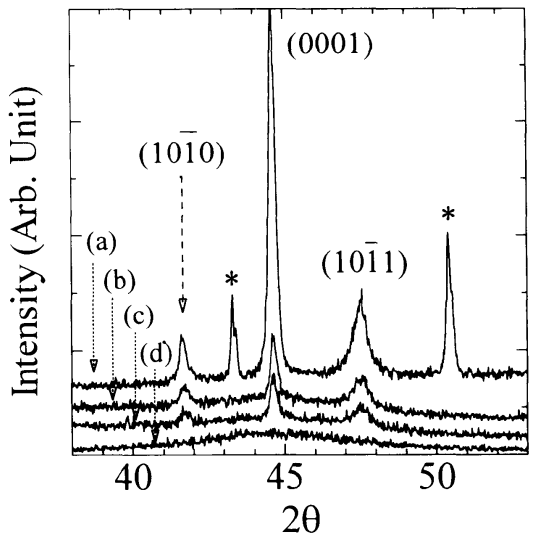

Fig. 6 X-ray diffraction curves of CoP alloy films $(\sim 1 \mu \mathrm{m}$ thickness) for (a) polycrystalline $\mathrm{Cu}$ substrate, (b) $\mathrm{FeCoSiB}$ (S 247) substrate, (c) $\mathrm{FeSiB}(\mathrm{S} 265$ ) substrate, and (d) only the $\mathrm{FeSiB}(\mathrm{S} 265)$ substrate.

$1 \mu \mathrm{m}$ 程度の膜厚が得られている。従って, 'いずれの場 合あ基板からの回折ピークがあわせて観測されている。 $\mathrm{Cu}$ 基板からの回折ピークは図中に*印で表わした。ま た, $\mathrm{FeSiB}(\mathrm{S} 265)$ 基板のみからのX 線回折曲線 (d) を 別に示した。 $\mathrm{Cu}$ 基板を用いた場合には，めっき層は多 結晶質で形成されていることが分かり，3つの面方位を もつ結晶配向性を示している。また，2つの組成の異な る非晶質基板を用いた場合 (b), (c) には，非晶質基板か らのハローなピークに重なる位置に $\mathrm{Cu}$ 基板と全く同様 の角度で回折ピークが得られている。これらの結果から は, $1 \mu \mathrm{m}$ 程度の膜厚をあつ CoPめっき膜は, 基板の結 晶性（結晶質か非晶質）に因らずに，ほぼ同様の優先配 向性をむつあの之考えられる。

これらの膜の表面形態をSEMにょり，Cu基板， $\mathrm{FeSiB}(\mathrm{S} 265$ ) 基板を用いた場合を比較し，図７に示す。 いずれの場合む, 粒の形状はほぼ一様で, 均一な膜を構 成している。しかし, 基板の結晶性により, 粒の形状, サイズが異なる。これについては, 非晶質基板のロール 面とフリ一面との比較, 触媒活性処理の影響などをさら に確認する必要がかる。

\section{4. 結言}

$\mathrm{Fe}$ 基非晶質基板上に無電解めっき法による $\mathrm{CoP}$ 薄膜 形成の可能性を電気化学的分極特性の観察から評価した。 酸化還元型の無電解めっきに対し，この非晶質基板は触 媒活性であるが，その作用は概して小さく，Pdによる 触媒活性処理を施すことにより実用的なめっき速度が得 られることが分かった。また, 分極曲線の観察から, $\mathrm{FeSiB}$ 非晶質基板のフリ一面の触媒活性は大きく, 触 媒化処理をしたロール面よりもめっき速度が大きいこと 
(a)

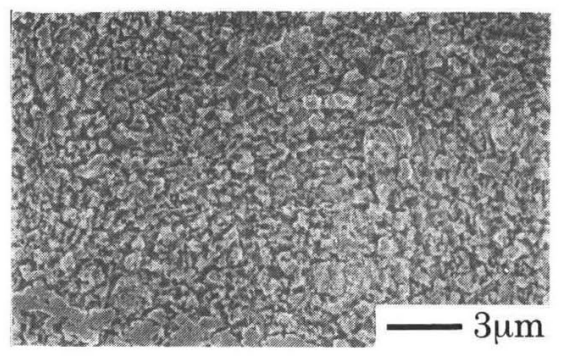

(b)

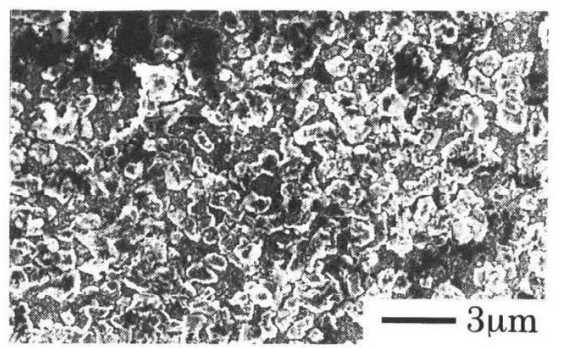

Fig. 7 Surface SEM images of CoP alloy films for (a) polycrystalline Cu substrate and (b) $\mathrm{FeSiB}$ (S 265) amorphous substrate.

が確認できた。さらに，分極特性の基板の組成依存性を 評価し, めっき速度は, めっき電位が卑になるに従い指 数関数的に増加した。このことは非晶質基板上への無電 解めっきの速度が, 基板の電極触媒活性に依存する可能
性を示唆した。実際に形成された $\mathrm{Fe}$ 基非晶質薄帯基板 上の $1 \mu \mathrm{m}$ 程度の膜厚の $\mathrm{CoP}$ 膜の結晶配向性は, 多結 晶 $\mathrm{Cu}$ 基板との比較から，基板の結晶性（結晶質か非晶 質）に影響されず，ほぼ同様であることを確認した。ま た, 成膜された無電解 $\mathrm{CoP}$ 膜は, 結晶粒の形状が一様, 均一であることを確認した。

\section{謝 辞}

非晶質薄帯は, 新日本製鐵(侏先端技術研究所, 山田利 男氏より御提供頂きました。蒸留水は, 本学金属工学科, 水流 徹教授より御提供頂きました。また, XRD測定, SEM 観察に関して, 本学金属工学科助手, 芳賀由美子 博士に御指導いただきました。諸氏に対し，記して，感 謝の意を表します。

(平成 8 年 3 月, 表面技術協会第 93 回講演大会におい て発表)

(Received July 6, 1996 ; Accepted November 17, 1996)

\section{文献}

1) 大野 湶, 春山志郎; 日本金属学会会報, 20，979（1981）

2) Y. Moradzadeh; J. Electrochem. Soc., 112, 891 (1965)

3 ) J. R. Depew ; J. Electrochem. Soc., 120, 1187 (1973)

4) R. D. Fisher and W. H. Chilton; Plating, 54, 537 (1967)

5 ) A. S. Frieze, R. Sard and R. Weil ; J. Electrochem. Soc., 115,586 (1968)

6) Modern Electroplating, 3rd edition Edited by F. A. Lowenheim, p. 731 (John Wiley \& Sons, Inc., 1974)

7 ) 石橋 知, 鷹野 修; 金属表面技術講座第 9 巻, 無電解メッ キ, p. 115，119 (金属表面技術協会編〕（朝倉書店，1968）

8 ) T.Sato ; Proc. of 1 st Int. Conf. on the Advanced Solidification Processing and Its Application, p. 203 (1993)

9）大野 湶, 松崎壮一, 春山志郎 ; 金属表面技術, 32, 75 (1981) 